\title{
Mn-mediated sequential three-component domino Knoevenagel/cyclization/Michael addition/ oxidative cyclization reaction towards annulated imidazo[1,2-a]pyridines
}

\author{
Olga A. Storozhenko ${ }^{1}$, Alexey A. Festa ${ }^{* 1}$, Delphine R. Bella Ndoutoume ${ }^{1}$, \\ Alexander V. Aksenov ${ }^{2}$, Alexey V. Varlamov ${ }^{1}$ and Leonid G. Voskressensky ${ }^{* 1}$
}

\author{
Full Research Paper \\ Address: \\ ${ }^{1}$ Organic Chemistry Department, Peoples' Friendship University of \\ Russia (RUDN University), Miklukho-Maklaya st. 6, 117198 Moscow, \\ Russian Federation and ${ }^{2}$ Department of Chemistry, North Caucasus \\ Federal University, Pushkin st. 1a, 355009 Stavropol, Russian \\ Federation \\ Email: \\ Alexey A. Festa* - festa_aa@pfur.ru; Leonid G. Voskressensky* - \\ Ivoskressensky@sci.pfu.edu.ru \\ ${ }^{*}$ Corresponding author \\ Keywords: \\ 2-aminochromene; domino reaction; imidazo[1,2-a]pyridine; \\ 2-iminochromene; Michael addition; multicomponent reaction; \\ oxidation; pyridine amination
}

Beilstein J. Org. Chem. 2018, 14, 3078-3087.

doi:10.3762/bjoc. 14.287

Received: 05 September 2018

Accepted: 26 November 2018

Published: 19 December 2018

This article is part of the thematic issue "Multicomponent reactions III".

Guest Editor: T. J. J. Müller

(c) 2018 Storozhenko et al.; licensee Beilstein-Institut.

License and terms: see end of document.

\begin{abstract}
The sequential three-component reaction between $o$-hydroxybenzaldehydes, $N$-(cyanomethyl)pyridinium salts and a nucleophile towards substituted chromenoimidazopyridines under oxidative conditions has been developed. The employment of $\mathrm{Mn}(\mathrm{OAc})_{3} \cdot 2 \mathrm{H}_{2} \mathrm{O}$ or $\mathrm{KMnO}_{4}$ as stoichiometric oxidants allowed the use of a wide range of nucleophiles, such as nitromethane, (aza)indoles, pyrroles, phenols, pyrazole, indazole and diethyl malonate. The formation of the target compounds presumably proceeds through a domino Knoevenagel/cyclization/Michael addition/oxidative cyclization reaction sequence.
\end{abstract}

\section{Introduction}

Domino reactions are well recognized for their ability to effectively synthesize organic compounds, as far as creating two and more chemical bonds in one-step decreases waste, resources and time, and makes the development of methodology of synthesis in a domino fashion a substantial task [1]. Recently, much attention in research was given to domino reactions with an oxidation step, revealing possibilities for shifting the equilibrium by making products more stable or in situ generating reactive intermediates [2-13]. In its turn, multicomponent reactions (MCRs), usually occurring as domino processes with three or 
more reactants mixed together, became a valuable tool for the synthetic chemistry to produce diverse and complex compounds in an efficient and sustainable way [14-17]. The use of oxidative conditions in MCRs was found to be useful [18], but challenging due to difficulty to match the redox potentials of three or more reactants at a time and employment of a sequential one-pot strategy may become one of the reasonable solutions.

The vast biological activity of the compounds, bearing the imidazo[1,2- $a]$ pyridine scaffold makes this heterocycle of great importance to the fields of medicinal chemistry and biology $[19,20]$, illustrated by the marketed drugs, e.g., alpidem, minodronic acid, olprinone, zolimidine (Figure 1) and some recent examples of the imidazopyridines inhibiting tubulin polymerization [21], NF- $\kappa \mathrm{B}$ [22], aldosterone synthase [23], or autotaxin [24]. Whereas many interesting approaches towards the imidazo[1,2- $a]$ pyridine core are being published nowadays [25-30], this molecular entity is still a pursued synthetic target and novel routes to diverse imidazopyridines are of value. Another privileged scaffold for drug discovery is 2-aminochromene, which may be found in crolibulin, an antitumor agent, undergoing phase II clinical trials [31], chromenotacrine CT-6, a potential anti-Alzheimer agent [32], and pranoprofen, a

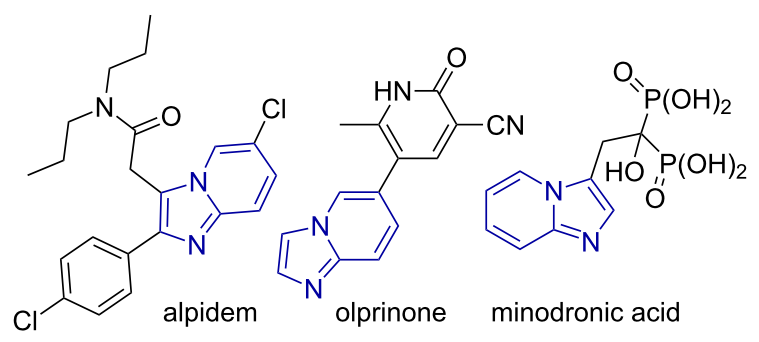<smiles>COc1ccccc1CCc1ccc(S(C)(=O)=O)cc1</smiles><smiles>COc1cc(C2c3ccc(O)cc3Oc3nc4c(c(N)c32)CCCC4)cc(OC)c1OC</smiles>
chromenotacrine CT6<smiles>COc1cc(C2C(C#N)=C(N)Oc3c2ccc(N)c3NC(C)(F)C(F)(F)F)cc(Br)c1OC</smiles>
pranoprofen

Figure 1: Biologically relevant imidazo[1,2-a]pyridines and chromenes marketed anti-inflammatory drug [33]. Combination of chromene and imidazopyridine rings led to the discovery of compound $\mathbf{A}$ with promising anticancer activity [34], thereby showing the importance of this merged heterocyclic skeleton (Figure 1).

The formation of the chromene and imidazole rings in a singlestep procedure was independently discovered by us [35,36] and Proença et al. [37,38], who identified 2-iminochromene 3 to be the key intermediate of the domino sequence (Scheme 1, reaction 1). Taking into account the capability of 2-iminochromenes to perform as Michael acceptors [39-41], we envisioned the diversification of the substitution pattern at the chromene ring to be a realizable and an appealing target, complicated by the need of an oxidant to fulfil the final aromatization. Following our interest in domino [42,43] and MCR chemistry [44,45] and taking an advantage of 2-iminochromene reactivity, herein we report a sequential three-component domino reaction of salicylaldehydes $\mathbf{2}$ and $N$-(cyanomethyl)pyridinium salts $\mathbf{1}$ with a broad scope of nucleophiles to produce diversely substituted valuable chromenoimidazopyridines under oxidative conditions (Scheme 1, reaction 2).

\section{(1) previous work:}

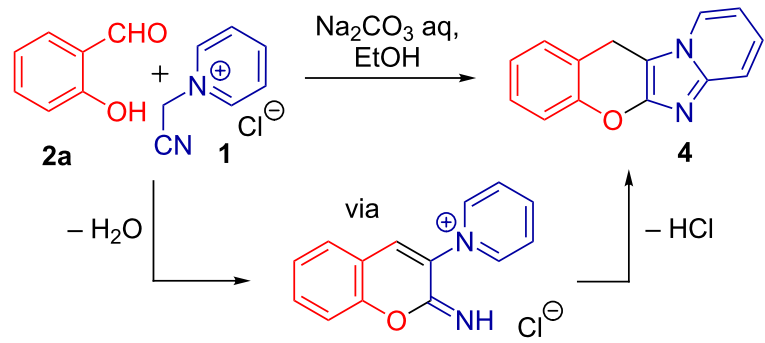

(2) this work:

$$
3
$$

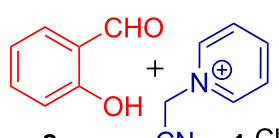

$$
\text { 1) } \mathrm{Et}_{3} \mathrm{~N} \text {, }
$$$$
\mathrm{CF}_{3} \mathrm{CH}_{2} \mathrm{OH}
$$

2) $\mathrm{NuH}$, oxidant<smiles>NC1c2ccccc2Oc2nc3ccccn3c21</smiles>

$2 \mathbf{a}$

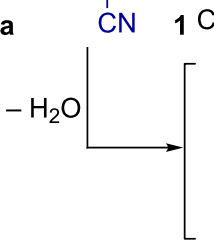

$l^{\ominus}$

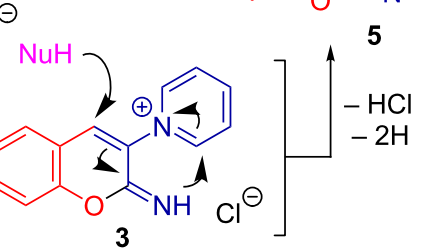

$\mathrm{NuH}=\pi$-nucleophiles, $\mathrm{CH}$ acids, $\mathrm{N}$-nucleophiles

Scheme 1: Domino formation of imidazopyridines and current work.

\section{Results and Discussion}

To prove the designed concept, the reaction between salicylaldehyde (2a), $N$-(cyanomethyl)pyridinium chloride (1) and nitromethane as a nucleophile was carried out in ethanol with triethylamine as a base under air atmosphere in a two-step 
fashion. Firstly, the quaternary salt was stirred with salicylaldehyde in the presence of triethylamine at $0{ }^{\circ} \mathrm{C}$ for $30 \mathrm{~min}$, and secondly nitromethane ( 10 equiv) was added and the mixture was refluxed for $2 \mathrm{~h}$ in an open vessel. As a result, the desired product 5a was isolated in trace amounts as a mixture with compound 4 (Table 1, entry 1). Performing the first step under cooling was found to be essential to avoid cyclization of 2-iminochromene intermediate 3 into the two-component reaction product $\mathbf{4}$. It is worth noting, that the conversion of $\mathbf{3}$ to $\mathbf{4}$ is a constant side reaction, occurring even at $\mathrm{rt}$ and complicating the process. Since the air oxygen was not enough to deliver the needed cyclization, we started to look for an appropriate oxidant. The addition of 1.1 equiv diacetoxyiodobenzene (PIDA) as an external oxidant on the second step and changing the solvent to trifluoroethanol allowed the isolation of the desired product 5a with $25 \%$ yield after 2 h reflux (Table 1 , entry 2), while leaving the reaction at $\mathrm{rt}$ for 7 days gave the compound 5a with $30 \%$ yield (Table 1, entry 3 ). Further screening of the oxidants revealed, that the use of molecular iodine gave the desired product with $27 \%$ yield (Table 1 , entry 4), while employment of $\mathrm{NaOCl}, \mathrm{NaIO}_{4}, \mathrm{MnO}_{2}, \mathrm{H}_{2} \mathrm{O}_{2}$, or $\mathrm{CuI} / \mathrm{TBHP}$ was not effective and led to the formation of complex mixtures (Table 1, entries 5-9), and use of CAN did not promote the reaction (Table 1, entry 10). The use of $\mathrm{KMnO}_{4}$ which is known as a classical oxidant for pyridine amination [46], gave desired chromenoimidazopyridine 5a with admissible $47 \%$ yield (Table 1 , entry 11 ). The yield of $54 \%$ was achieved with $\mathrm{Mn}(\mathrm{OAc})_{3} \cdot 2 \mathrm{H}_{2} \mathrm{O}$ (Table 1 , entry 12 ), while increasing the reaction time of the first step gave product $5 \mathbf{a}$ with good 64\% yield (Table 1, entry 13). The use of EtOH as a solvent was found inappropriate, as the yield was decreased by $21 \%$ (Table 1 , entry 14 ), and reducing the amount of nitro-

Table 1: Optimization of reaction conditions with nitromethane nucleophile.

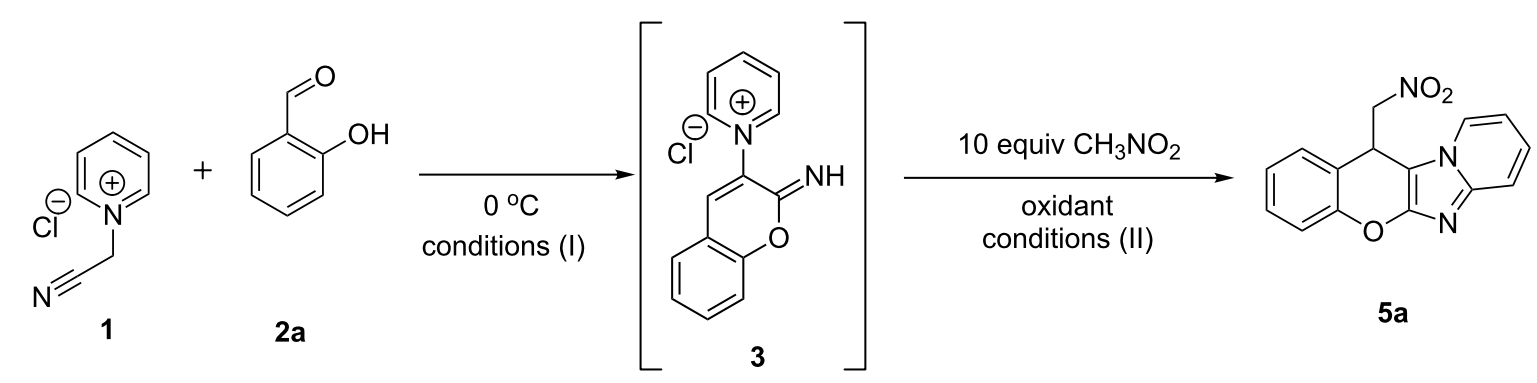

\begin{tabular}{|c|c|c|c|c|}
\hline entry & conditions (I) & oxidant (equiv) & conditions (II) & yield of $5 \mathbf{a}(\%)$ \\
\hline 1 & $\mathrm{Et}_{3} \mathrm{~N}$ (1 equiv), $0^{\circ} \mathrm{C}, \mathrm{EtOH}, 0.5 \mathrm{~h}$ & no oxidant & reflux, $2 \mathrm{~h}$ & traces \\
\hline 2 & $\mathrm{Et}_{3} \mathrm{~N}$ (1 equiv), $0^{\circ} \mathrm{C}$, TFE, $0.5 \mathrm{~h}$ & PIDA (1.1 equiv) & $\mathrm{Et}_{3} \mathrm{~N}$ (2 equiv), reflux, $2 \mathrm{~h}$ & 25 \\
\hline 3 & $\mathrm{Et}_{3} \mathrm{~N}$ ( 1 equiv), $0^{\circ} \mathrm{C}, \mathrm{TFE}, 0.5 \mathrm{~h}$ & PIDA (1.1 equiv) & $\mathrm{Et}_{3} \mathrm{~N}$ (2 equiv), rt, 7 days & 30 \\
\hline 4 & $\mathrm{Et}_{3} \mathrm{~N}$ (0.2 equiv), $0^{\circ} \mathrm{C}, \mathrm{TFE}, 1 \mathrm{~h}$ & $\mathrm{I}_{2}$ (1 equiv) & $\mathrm{Et}_{3} \mathrm{~N}(0.8$ equiv), reflux, $1 \mathrm{~h}$ & 27 \\
\hline 5 & $\mathrm{Et}_{3} \mathrm{~N}$ (1 equiv), $0{ }^{\circ} \mathrm{C}, \mathrm{TFE}, 0.5 \mathrm{~h}$ & $\mathrm{NaOCl}$ ( $5 \%$ aq, 3 equiv) & $\mathrm{Et}_{3} \mathrm{~N}$ (1 equiv), reflux, $1 \mathrm{~h}$ & complex mixture \\
\hline 6 & $\mathrm{Et}_{3} \mathrm{~N}$ (1 equiv), $0^{\circ} \mathrm{C}, \mathrm{TFE}, 0.5 \mathrm{~h}$ & $\mathrm{NalO}_{4}$ (0.5 equiv) & $\mathrm{Et}_{3} \mathrm{~N}$ (1 equiv), reflux, $1 \mathrm{~h}$ & complex mixture \\
\hline 7 & $\mathrm{Et}_{3} \mathrm{~N}$ ( 1 equiv), $0{ }^{\circ} \mathrm{C}, \mathrm{TFE}, 0.5 \mathrm{~h}$ & $\mathrm{MnO}_{2}$ (2 equiv) & $\mathrm{Et}_{3} \mathrm{~N}$ (1 equiv), reflux, $1 \mathrm{~h}$ & complex mixture \\
\hline 8 & $\mathrm{Et}_{3} \mathrm{~N}$ ( 1 equiv), $0^{\circ} \mathrm{C}, \mathrm{TFE}, 0.5 \mathrm{~h}$ & $33 \%$ aq $\mathrm{H}_{2} \mathrm{O}_{2}$ (2 equiv) & $\mathrm{Et}_{3} \mathrm{~N}$ (1 equiv), reflux, $1 \mathrm{~h}$ & complex mixture \\
\hline 9 & $\mathrm{Et}_{3} \mathrm{~N}$ (1 equiv), $0{ }^{\circ} \mathrm{C}, \mathrm{TFE}, 0.5 \mathrm{~h}$ & $\begin{array}{l}\text { Cul ( } 0.1 \text { equiv)/TBHP } \\
\text { ( } 2 \text { equiv, } 70 \% \text { aq) }\end{array}$ & $\mathrm{Et}_{3} \mathrm{~N}$ (1 equiv), reflux, $1 \mathrm{~h}$ & complex mixture \\
\hline 10 & $\mathrm{Et}_{3} \mathrm{~N}$ (1 equiv), $0{ }^{\circ} \mathrm{C}$, TFE, $0.5 \mathrm{~h}$ & CAN (2 equiv) & $\mathrm{Et}_{3} \mathrm{~N}$ (1 equiv), reflux, $1 \mathrm{~h}$ & - \\
\hline 11 & $\mathrm{Et}_{3} \mathrm{~N}$ (0.2 equiv), $0^{\circ} \mathrm{C}, \mathrm{TFE}, 1 \mathrm{~h}$ & $\mathrm{KMnO}_{4}$ (1 equiv) & $\mathrm{Et}_{3} \mathrm{~N}(0.8$ equiv $)$, reflux, $1 \mathrm{~h}$ & 47 \\
\hline 12 & $\mathrm{Et}_{3} \mathrm{~N}$ ( 1 equiv), $0{ }^{\circ} \mathrm{C}, \mathrm{TFE}, 0.5 \mathrm{~h}$ & $\mathrm{Mn}(\mathrm{OAc})_{3} \cdot 2 \mathrm{H}_{2} \mathrm{O}$ (2 equiv) & $\mathrm{Et}_{3} \mathrm{~N}$ (1 equiv), reflux, $1 \mathrm{~h}$ & 54 \\
\hline 13 & $\mathrm{Et}_{3} \mathrm{~N}$ (0.2 equiv), $0^{\circ} \mathrm{C}, \mathrm{TFE}, 1 \mathrm{~h}$ & $\mathrm{Mn}(\mathrm{OAc})_{3} \cdot 2 \mathrm{H}_{2} \mathrm{O}$ (2 equiv) & $\mathrm{Et}_{3} \mathrm{~N}$ (1.8 equiv), reflux, $1 \mathrm{~h}$ & 64 \\
\hline 14 & $\mathrm{Et}_{3} \mathrm{~N}(0.2$ equiv $), 0^{\circ} \mathrm{C}, \mathrm{ETOH}$ dry, $1 \mathrm{~h}$ & $\mathrm{Mn}(\mathrm{OAc})_{3} \cdot 2 \mathrm{H}_{2} \mathrm{O}$ (2 equiv) & $\mathrm{Et}_{3} \mathrm{~N}$ (1.8 equiv), reflux, $1 \mathrm{~h}$ & 43 \\
\hline $15^{\mathrm{a}}$ & $\mathrm{Et}_{3} \mathrm{~N}$ (0.2 equiv), $0^{\circ} \mathrm{C}, \mathrm{TFE}, 1 \mathrm{~h}$ & $\mathrm{Mn}(\mathrm{OAc})_{3} \cdot 2 \mathrm{H}_{2} \mathrm{O}$ (2 equiv) & $\mathrm{Et}_{3} \mathrm{~N}$ (1.8 equiv), reflux, $1 \mathrm{~h}$ & 59 \\
\hline 16 & DIPEA (0.2 equiv), $0{ }^{\circ} \mathrm{C}, \mathrm{TFE}, 1 \mathrm{~h}$ & $\mathrm{Mn}(\mathrm{OAc})_{3} \cdot 2 \mathrm{H}_{2} \mathrm{O}$ (2 equiv) & DIPEA (1.8 equiv), reflux, $1 \mathrm{~h}$ & 55 \\
\hline 17 & DABCO (0.2 equiv), $0^{\circ} \mathrm{C}, \mathrm{TFE}, 1 \mathrm{~h}$ & $\mathrm{Mn}(\mathrm{OAc})_{3} \cdot 2 \mathrm{H}_{2} \mathrm{O}$ (2 equiv) & DABCO (1.8 equiv), reflux, $1 \mathrm{~h}$ & 42 \\
\hline 18 & $\mathrm{~K}_{2} \mathrm{CO}_{3}$ (0.2 equiv), $0{ }^{\circ} \mathrm{C}, \mathrm{TFE}, 1 \mathrm{~h}$ & $\mathrm{Mn}(\mathrm{OAc})_{3} \cdot 2 \mathrm{H}_{2} \mathrm{O}$ (2 equiv) & $\mathrm{K}_{2} \mathrm{CO}_{3}$ (1.8 equiv), reflux, $1 \mathrm{~h}$ & 36 \\
\hline 19 & $\mathrm{Et}_{3} \mathrm{~N}$ (0.2 equiv), $0^{\circ} \mathrm{C}, \mathrm{TFE}, 1 \mathrm{~h}$ & $\mathrm{Mn}(\mathrm{OAc})_{3} \cdot 2 \mathrm{H}_{2} \mathrm{O}$ (2 equiv) & $\mathrm{Et}_{3} \mathrm{~N}$ (3.8 equiv), reflux, $1 \mathrm{~h}$ & 64 \\
\hline
\end{tabular}

a 5 equiv $\mathrm{CH}_{3} \mathrm{NO}_{2}$ was used instead of 10 equiv. 
methane lowered the yield by $5 \%$ (Table 1 , entry 15 ). Use of DIPEA (Table 1, entry 16), DABCO (Table 1, entry 17) or $\mathrm{K}_{2} \mathrm{CO}_{3}$ (Table 1, entry 18) did not increase the yield of 5a. Increasing the amount of $\mathrm{Et}_{3} \mathrm{~N}$ to 3.8 equiv at the second step allowed to suppress the formation of byproduct 22 (Scheme 6, reaction 2, IV) and simplified the isolation of 5a (Table 1, entry 19 , further referred to as optimal conditions), probably due to improved solubility of manganese salt.

To understand the scope of this three-component reaction of nitromethane, the optimized conditions were used with different $o$-hydroxybenzaldehydes to prepare products $\mathbf{5 a}-\mathbf{h}$ with $37-68 \%$ yields, displaying tolerance to diverse substitution patterns in the aldehyde component (Scheme 2).

According to the literature [47-52], the introduction of an indole core into a chromene moiety is an appealing task, which prompted us to investigate the possibility to use this nucleophile in the discovered process. The previously optimized conditions worked nicely for the reaction of $N$-(cyanomethyl)pyridinium chloride, $o$-hydroxybenzaldehyde and indole, pro- ducing the desired compound 6a with good $77 \%$ yield (Scheme 3, footnote a). Unfortunately, the employment of $\mathrm{N}$-methylindole resulted in the formation of the inseparable mixture of the target compound $\mathbf{6 b}$ and the two-component reaction product 4 (Scheme 3, footnote b), showing the need for more general reaction conditions. It occurred that the use of $\mathrm{KMnO}_{4}$ as an oxidant was advantageous, though giving $6 \mathbf{a}$ with a slightly lower yield of $69 \%$, but furnishing $N$-methylindole product $6 \mathrm{~b}$ with $54 \%$ (Scheme 3, footnote c). Further investigation of the reaction scope gave rise to a series of diversely substituted chromenoimidazopyridines $\mathbf{6 c}-\mathbf{k}$, demonstrating high synthetic potential of the transformation (Scheme 3 ).

To show the generality of the chosen oxidant, broad scope of nucleophiles was tested under selected conditions. Thus, employment of pyrrole as a nucleophile gave product $7 \mathbf{a}$ in $43 \%$ yield, and $N$-methylpyrrole facilitated desired compound $\mathbf{7 b}$ in $23 \%$ yield (Scheme 4). Isomeric 5-, 6- and 7-azaindoles were found to be appropriate nucleophiles too, producing the corresponding molecules $\mathbf{8}-\mathbf{1 0}$, in $60 \%, 53 \%$ and $49 \%$ yields, respectively.

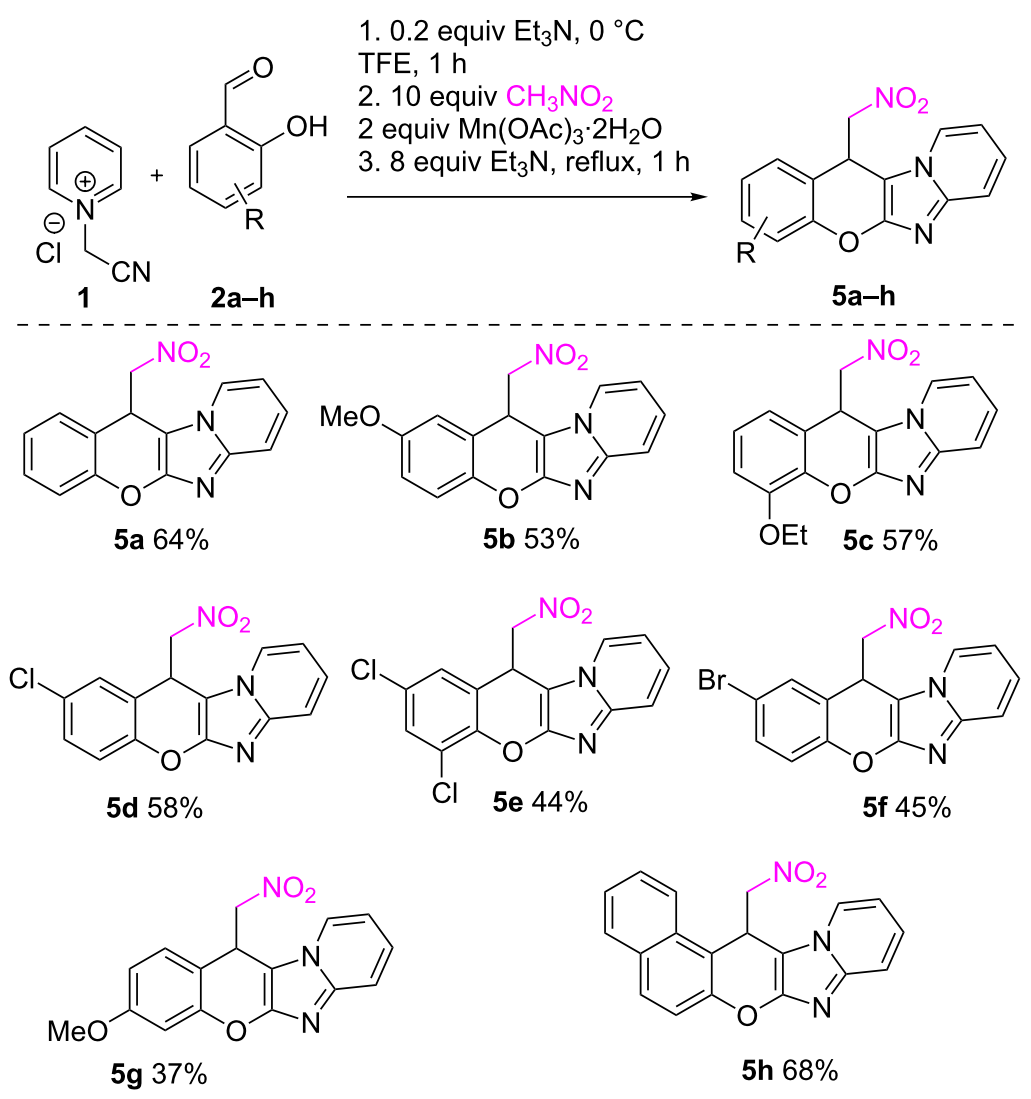




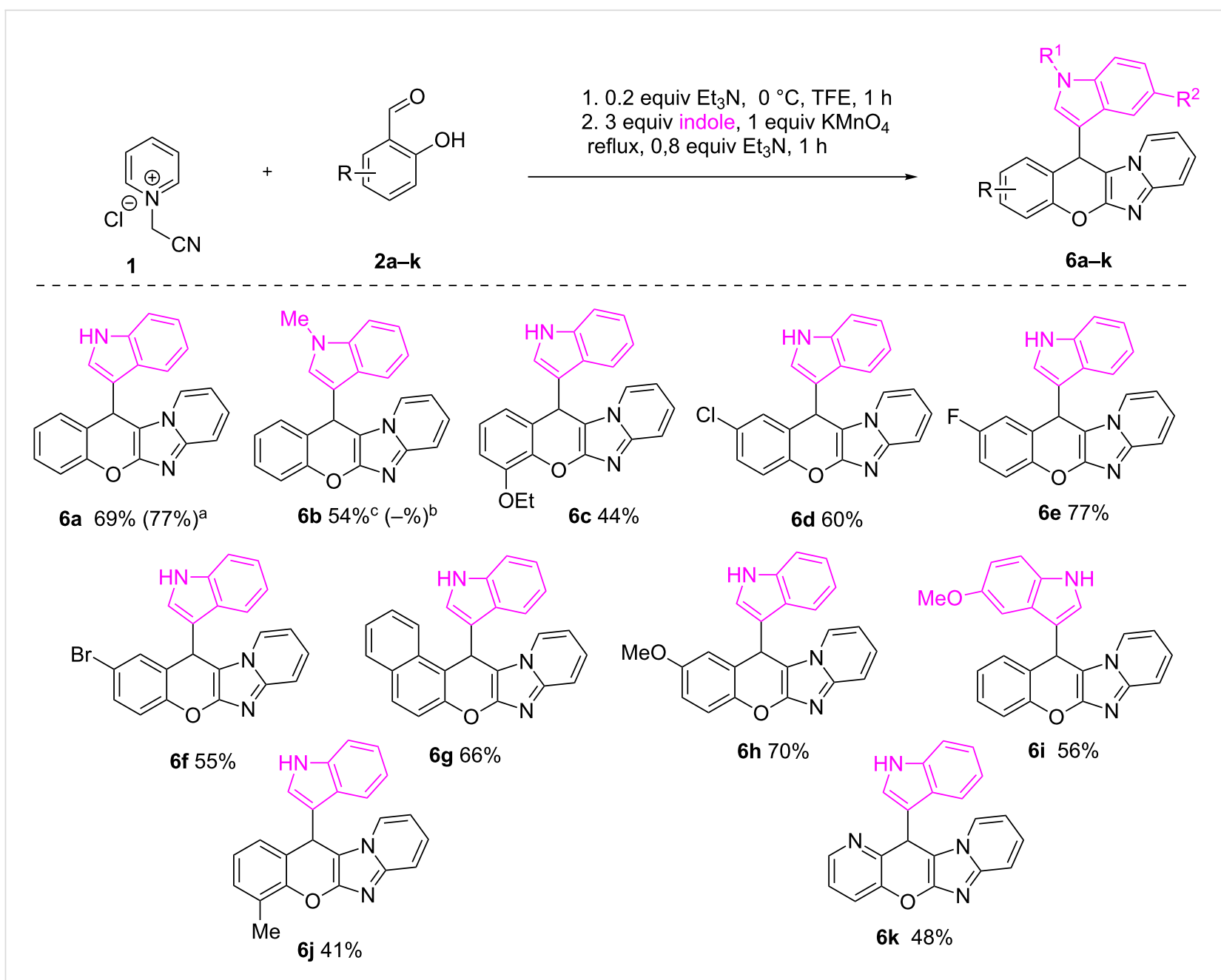

Scheme 3: Scope of the reaction of o-hydroxybenzaldehydes with $\mathrm{N}$-(cyanomethyl)pyridinium chloride and indoles. ${ }^{\text {a }} 2$ equiv $\mathrm{Mn}(\mathrm{OAc})_{3} \cdot 2 \mathrm{H}_{2} \mathrm{O}$ was

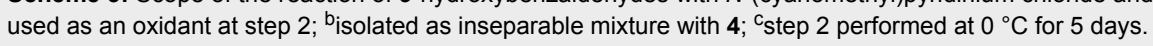

Such well-known $\pi$-nucleophiles as phenols could be used for the reaction, though 3-methoxyphenol and 3,5-dimethoxyphenol gave inseparable mixtures of regioisomers 11a and 11b (NMR, LCMS). The reactions with $p$-isopropyl- and $p$-tertbutylphenols gave only one isomer, but the yields of the corresponding products 11c and 11d were low. Employed as $\mathrm{N}$-nucleophiles, pyrazole and benzopyrazole successfully formed products 12 and 13, correspondingly, with moderate yields. The possibility to employ $\mathrm{CH}$-acids as nucleophiles was finally demonstrated on diethyl malonate, providing compounds $14 \mathbf{a}-\mathbf{c}$ in $40-58 \%$ yields.

To conclusively reveal the scope of the reaction, we exploited $\mathrm{N}$-cyanomethyl quaternary salts of fused thieno[2,3-c]pyridine $\mathbf{1 5}$ and 1-methyl-6-azaindole $\mathbf{1 6}$ in this transformation. Therefore, annulated chromenoimidazoles 17-20 were effectively produced in a sequential three-component manner (Scheme 5).
The structures of the synthesized compounds $5 \mathbf{a}-\mathbf{h}, \mathbf{6 a}-\mathbf{k}, \mathbf{7}-\mathbf{1 4}$, 17-20 were confirmed by ${ }^{1} \mathrm{H},{ }^{13} \mathrm{C}$ NMR, IR spectroscopy and HRMS spectra (see Supporting Information File 1 for details). The structure of the compound $\mathbf{7 b}$ was unambiguously determined by a single crystal X-ray diffraction study (Figure 2).

The sequential domino reaction presumably starts with the Knoevenagel condensation of $o$-hydroxybenzaldehyde and $N$-(cyanomethyl)pyridinium salt forming styryl derivative A, which undergoes intramolecular cyclization to give 2-iminochromene salt 3. Subsequent treatment of the reaction mixture with nucleophile, oxidant and a base leads to the Michael addition on $\mathrm{C}(4)$ of the chromene ring to produce 2-aminochromene B with incorporated nucleophilic moiety. Further cyclization and deprotonation furnishes anion $\mathbf{C}$, which is easily oxidized to final product 5 (Scheme 6, reaction 1). The key 2-iminochromene intermediate $\mathbf{3}$ may be isolated as a perchlorate salt with $80 \%$ yield (Scheme 6 , reaction 2 ). To confirm the reaction 


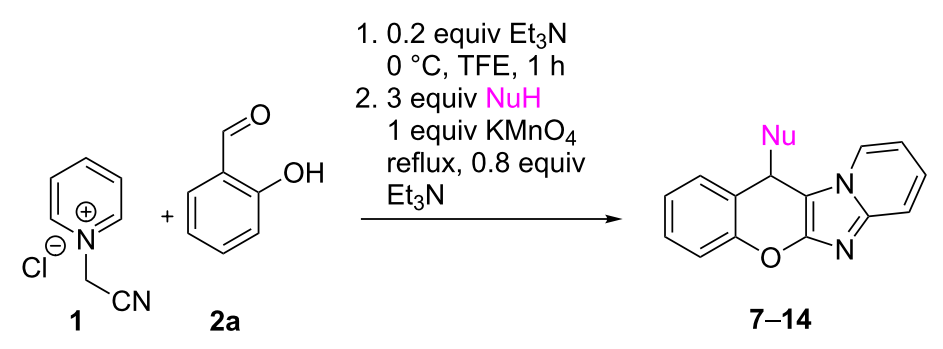<smiles>[R]n1cccc1C1c2ccccc2Oc2nc3ccccn3c21</smiles>

$7 \mathrm{a}, \mathbf{b}^{\mathrm{a}}$

7a: $\mathrm{R}=\mathrm{H}, 43 \%$

$7 b: R=M e, 23 \%$<smiles>c1ccc2c(c1)Oc1nc3ccccn3c1C2c1c[nH]c2ccncc12</smiles>

$1060 \%$<smiles>COc1ccc(C2c3ccccc3Oc3nc4ccccn4c32)c(O)c1</smiles>

11b $29 \%$<smiles>c1ccc2c(c1)Oc1nc3ccccn3c1C2c1c[nH]c2ncccc12</smiles>

$849 \%$<smiles>c1ccc2c(c1)Oc1nc3ccccn3c1C2c1c[nH]c2cnccc12</smiles>

$953 \%$<smiles>COc1cc(O)c(C2c3ccccc3Oc3nc4ccccn4c32)c(OC)c1</smiles><smiles>COc1cc(O)cc(OC)c1C1c2ccccc2Oc2nc3ccccn3c21</smiles>

NMR, ESIMS: $m / z 375[\mathrm{M}+\mathrm{H}]^{+}$<smiles>COc1cc(O)ccc1C1c2ccccc2Oc2nc3ccccn3c21</smiles><smiles>CC(C)(C)c1ccc(O)c(C2c3ccccc3Oc3nc4ccccn4c32)c1</smiles>

NMR, ESIMS: $m / z 345[\mathrm{M}+\mathrm{H}]^{+}$<smiles>CC(C)c1ccc(O)c(C2c3ccccc3Oc3nc4ccccn4c32)c1</smiles>

$11 d^{a} 18 \%$<smiles>c1ccc2c(c1)Oc1nc3ccccn3c1C2n1cccn1</smiles>

$1256 \%$<smiles>c1ccc2c(c1)Oc1nc3ccccn3c1C2n1ncc2ccccc21</smiles>

$1337 \%$<smiles>[R]c1cc2c(c([R])c1[R])C(C(C(=O)OCC)C(=O)OCC)c1c(nc3ccccn13)O2</smiles>

14a: $R^{1}=R^{2}=R^{3}=H, 58 \%$

14b: $R^{1}=H, R^{2}=$ OMe, $R^{3}=H, 52 \%$

14c: $R^{1}=H, R^{2}=R^{3}=, 40 \%$ 


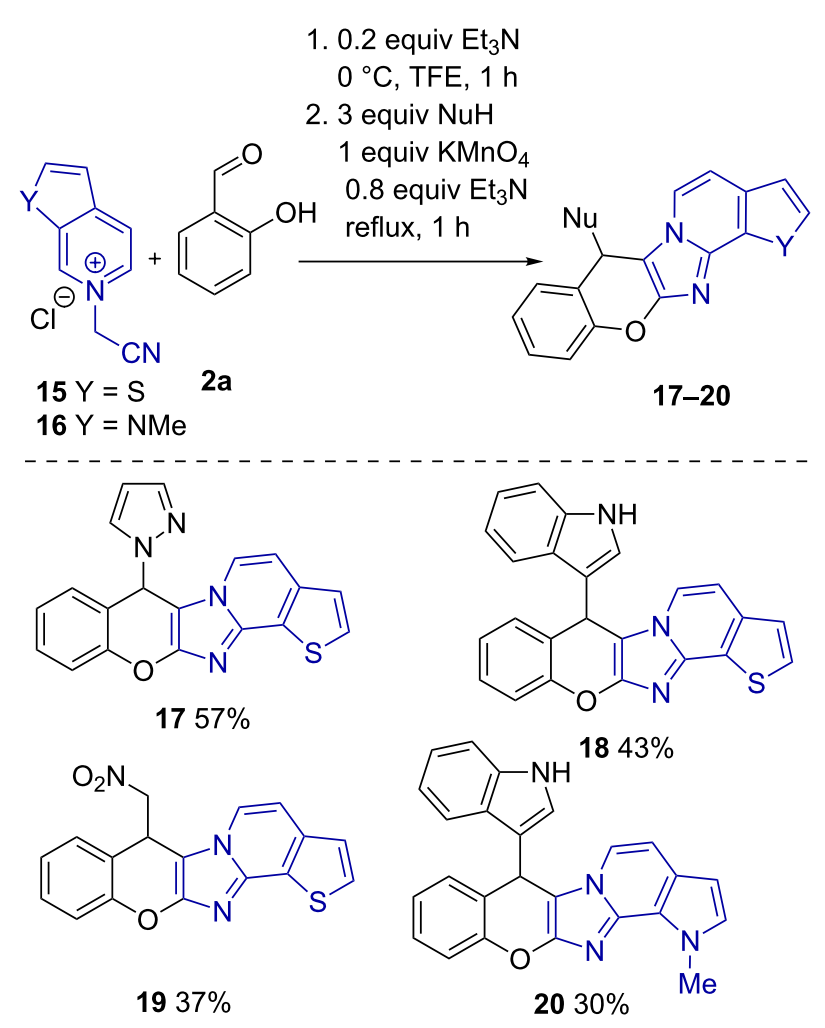

Scheme 5: $\mathrm{N}$-(Cyanomethyl)thieno[2,3-c]pyridinium chloride (15) and 6-(cyanomethyl)-1-methyl-1H-pyrrolo[2,3-c]pyridin-6-ium chloride (16) in reactions with salicylaldehyde and different nucleophiles. asecond step was performed at $0{ }^{\circ} \mathrm{C}$, for 7 days; ${ }^{b} 10$ equiv of $\mathrm{CH}_{3} \mathrm{NO}_{2}$ was used.

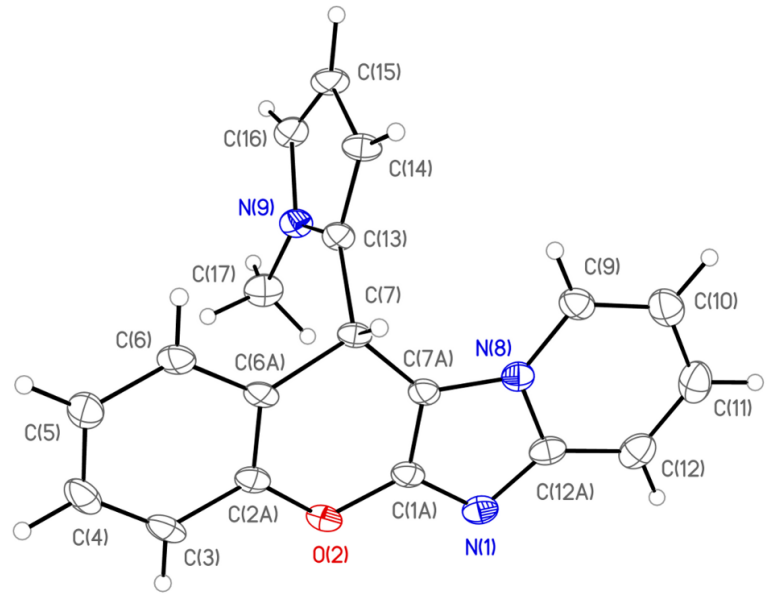

Figure 2: General view of the molecule $\mathbf{7 b}$ in the crystal state (CCDC 1849215). Anisotropic displacement parameters are drawn at $50 \%$ probability.

pathway, perchlorate $\mathbf{3}$ was converted into the product $\mathbf{5 a}$ under the standard conditions with $71 \%$ yield (Scheme 6 , reaction 2 , I). Without an external oxidant, the reaction of perchlorate $\mathbf{3}$ with nitromethane fails to give the desired product, while com- pound 21, arisen from nucleophilic attack on pyridinium moiety, was the only isolated material (Scheme 6, reaction 2, II). Without a nucleophile, the perchlorate $\mathbf{3}$ was confidently converted into the product 4 with $81 \%$ yield (Scheme 6 , reaction 2, III). The importance of the base on a second step of the transformation and its involvement in the oxidation part was affirmed experimentally. Thus, when the reaction was performed under the standard conditions, but no triethylamine was added at the second step, target product 5a was not observed, and compound $\mathbf{2 2}$ was isolated in trace amounts. Its formation may be explained by an initial nucleophilic addition of water to intermediate chromene 3 , oxidation to keto-derivative and condensation with nitromethane (Scheme 6, reaction 2, IV).

\section{Conclusion}

In conclusion, we have developed a practical route towards substituted chromenoimidazopyridines through a sequential three-component domino Knoevenagel/cyclization/Michael addition/oxidative cyclization reaction, employing cheap and abundant oxidants. The discovered process works in a broad substrate scope with special emphasis to the tolerance to a wide range of nucleophiles, despite high proximity of the nucleophilic and reductive properties. We presume the transformation finds its place in the diversity-oriented synthesis toolbox to 


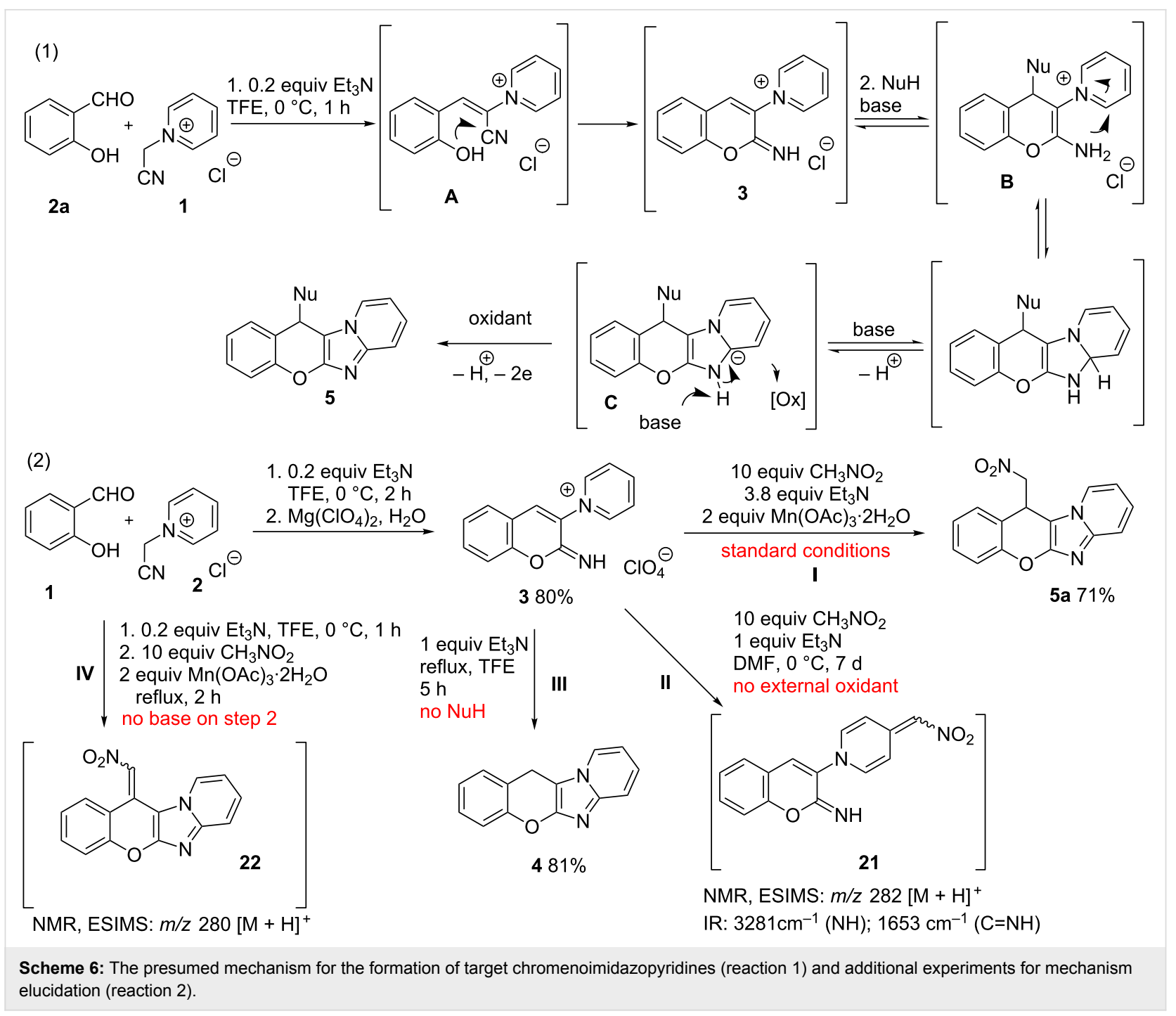

produce libraries of chromenoimidazoles with complex substitution and annulation patterns.

\section{Supporting Information}

\section{Supporting Information File 1}

Experimental part, copies of NMR spectra and X-ray diffraction data.

[https://www.beilstein-journals.org/bjoc/content/ supplementary/1860-5397-14-287-S1.pdf]

\section{Acknowledgements}

The publication was prepared with the support of the "RUDN University Program 5-100" and RFBR Grant 18-33-00536. A.A.F and L.G.V express sincere gratitude to Prof. Lutz F. Tietze for an inspirational meeting in the University of Göttingen.

\section{ORCID ${ }^{\circledR}$ iDs}

Alexey A. Festa - https://orcid.org/0000-0002-5113-1938 Alexander V. Aksenov - https://orcid.org/0000-0002-6644-9949 Leonid G. Voskressensky - https://orcid.org/0000-0002-9676-5846

\section{References}

1. Tietze, L. F. Domino Reactions: Concepts for Efficient Organic Synthesis; Wiley-VCH, 2014; p 648. doi:10.1002/9783527671304

2. Li, D.; Zeng, F. Org. Lett. 2017, 19, 6498-6501. doi:10.1021/acs.orglett.7b03164

3. Men, Y.; Dong, J.; Wang, S.; Xu, X. Org. Lett. 2017, 19, 6712-6715. doi:10.1021/acs.orglett.7b03434

4. Su, Z.; Gu, W.; Qian, S.; Xue, S.; Wang, C. Eur. J. Org. Chem. 2018, 1019-1025. doi:10.1002/ejoc.201701674

5. Furuta, M.; Hanaya, K.; Sugai, T.; Shoji, M. Tetrahedron 2017, 73, 2316-2322. doi:10.1016/j.tet.2017.03.021

6. Li, Z.; Wu, S.-S.; Luo, Z.-G.; Liu, W.-K.; Feng, C.-T.; Ma, S.-T. J. Org. Chem. 2016, 81, 4386-4392. doi:10.1021/acs.joc.6b00569

7. Liu, Y.; Hu, H.; Wang, X.; Zhi, S.; Kan, Y.; Wang, C. J. Org. Chem. 2017, 82, 4194-4202. doi:10.1021/acs.joc.7b00180 
8. Tang, S.; Liu, K.; Long, Y.; Gao, X.; Gao, M.; Lei, A. Org. Lett. 2015, 17, 2404-2407. doi:10.1021/acs.orglett.5b00912

9. Wu, B.; Gao, X.; Yan, Z.; Chen, M.-W.; Zhou, Y.-G. Org. Lett. 2015, 17, 6134-6137. doi:10.1021/acs.orglett.5b03148

10. Lou, J.; Wang, Q.; Wu, K.; Wu, P.; Yu, Z. Org. Lett. 2017, 19, 3287-3290. doi:10.1021/acs.orglett.7b01431

11. Gebauer, K.; Reuß, F.; Spanka, M.; Schneider, C. Org. Lett. 2017, 19, 4588-4591. doi:10.1021/acs.orglett.7b02185

12. Yue, Y.; Zhang, Y.; Song, W.; Zhang, X.; Liu, J.; Zhuo, K. Adv. Synth. Catal. 2014, 356, 2459-2464. doi:10.1002/adsc.201400097

13. Pandey, K.; Rangan, K.; Kumar, A. J. Org. Chem. 2018, 83, 8026-8035. doi:10.1021/acs.joc.8b00884

14. Ibarra, I. A.; Islas-Jácome, A.; González-Zamora, E. Org. Biomol. Chem. 2018, 16, 1402-1418. doi:10.1039/c7ob02305g

15. Dömling, A.; Wang, W.; Wang, K. Chem. Rev. 2012, 112, 3083-3135. doi:10.1021/cr100233r

16. Volla, C. M. R.; Atodiresei, I.; Rueping, M. Chem. Rev. 2014, 114, 2390-2431. doi:10.1021/cr400215u

17. D'Souza, D. M.; Müller, T. J. J. Chem. Soc. Rev. 2007, 36, 1095-1108. doi:10.1039/b608235c

18. Moni, L.; Banfi, L.; Riva, R.; Basso, A. Synthesis 2016, 48, 4050-4059. doi:10.1055/s-0035-1562527

19. Deep, A.; Bhatia, R. K.; Kaur, R.; Kumar, S.; Jain, U. K.; Singh, H.; Batra, S.; Kaushik, D.; Deb, P. K. Curr. Top. Med. Chem. 2017, 17, 238-250. doi:10.2174/1568026616666160530153233

20. Goel, R.; Luxami, V.; Paul, K. Curr. Top. Med. Chem. 2016, 16, 3590-3616. doi:10.2174/1568026616666160414122644

21. Ramya, P. V. S.; Guntuku, L.; Angapelly, S.; Digwal, C. S.; Lakshmi, U. J.; Sigalapalli, D. K.; Babu, B. N.; Naidu, V. G. M.; Kamal, A. Eur. J. Med. Chem. 2018, 143, 216-231. doi:10.1016/j.ejmech.2017.11.010

22. Vasu, K. K.; Digwal, C. S.; Pandya, A. N.; Pandya, D. H.; Sharma, J. A.; Patel, S.; Agarwal, M. Bioorg. Med. Chem. Lett. 2017, 27, 5463-5466. doi:10.1016/j.bmcl.2017.10.060

23. Whitehead, B. R.; Lo, M. M.-C.; Ali, A.; Park, M. K.; Hoyt, S. B.; Xiong, Y.; Cai, J.; Carswell, E.; Cooke, A.; MacLean, J.; Ratcliffe, P.; Robinson, J.; Bennett, D. J.; Clemas, J. A.; Wisniewski, T.; Struthers, M.; Cully, D.; MacNeil, D. J. Bioorg. Med. Chem. Lett. 2017, 27, 143-146. doi:10.1016/j.bmcl.2016.12.003

24. Desroy, N.; Housseman, C.; Bock, X.; Joncour, A.; Bienvenu, N.; Cherel, L.; Labeguere, V.; Rondet, E.; Peixoto, C.; Grassot, J.-M.; Picolet, O.; Annoot, D.; Triballeau, N.; Monjardet, A.; Wakselman, E.; Roncoroni, V.; Le Tallec, S.; Blanque, R.; Cottereaux, C.; Vandervoort, N.; Christophe, T.; Mollat, P.; Lamers, M.; Auberval, M.; Hrvacic, B.; Ralic, J.; Oste, L.; van der Aar, E.; Brys, R.; Heckmann, B. J. Med. Chem. 2017, 60, 3580-3590. doi:10.1021/acs.jmedchem.7b00032

25. Pericherla, K.; Kaswan, P.; Pandey, K.; Kumar, A. Synthesis 2015, 47, 887-912. doi:10.1055/s-0034-1380182

26. Bagdi, A. K.; Santra, S.; Monir, K.; Hajra, A. Chem. Commun. 2015, 51, 1555-1575. doi:10.1039/c4cc08495k

27. Ravi, C.; Adimurthy, S. Chem. Rec. 2017, 17, 1019-1038. doi:10.1002/tcr.201600146

28. Pandey, K.; Kaswan, P.; Saroy; Kumar, A. ChemistrySelect 2016, 1 , 6669-6672. doi:10.1002/slct.201601294

29. Balalaie, S.; Derakhshan-Panah, F.; Zolfigol, M. A.; Rominger, F. Synlett 2018, 29, 89-93. doi:10.1055/s-0036-1590906
30. Guo, P.; Huang, S.; Mo, J.; Chen, X.; Jiang, H.; Chen, W.; Cai, H.; Zhan, H. Catal. Commun. 2017, 90, 43-46. doi:10.1016/j.catcom.2016.10.033

31. Cai, S. X.; Drewe, J.; Kemnitzer, W. Anti-Cancer Agents Med. Chem. 2009, 9, 437-456. doi:10.2174/1871520610909040437

32. Akyol-Salman, İ.; Leçe-Sertöz, D.; Baykal, O. J. Ocul. Pharmacol. Ther 2007, 23, 280-283. doi:10.1089/jop.2006.108

33. Oset-Gasque, M. J.; González, M. P.; Pérez-Peña, J.; García-Font, N.; Romero, A.; del Pino, J.; Ramos, E.; Hadjipavlou-Litina, D.; Soriano, E.; Chioua, M.; Samadi, A.; Raghuvanshi, D. S.; Singh, K. N.; Marco-Contelles, J. Eur. J. Med. Chem. 2014, 74, 491-501. doi:10.1016/j.ejmech.2013.12.021

34. Lima, C. F.; Costa, M.; Proença, M. F.; Pereira-Wilson, C. Eur. J. Pharm. Sci. 2015, 72, 34-45. doi:10.1016/j.ejps.2015.02.019

35. Safarov, S.; Voskressensky, L. G.; Bizhko, O. V.; Kulikova, L. N.; Khrustalev, V. N. Acta Crystallogr., Sect. E: Struct. Rep. Online 2010, 66, o710. doi:10.1107/s1600536810006744

36. Voskressensky, L. G.; Kulikova, L. N.; Listratova, A. V.; Borisov, R. S.; Kukaniev, M. A.; Varlamov, A. V. Tetrahedron Lett. 2010, 51, 2269-2270. doi:10.1016/j.tetlet.2010.02.102

37. Proença, M. F.; Costa, M. Tetrahedron 2010, 66, 4542-4550. doi:10.1016/j.tet.2010.04.059

38. Costa, M.; Proença, M. F. Tetrahedron 2011, 67, 8622-8627. doi:10.1016/j.tet.2011.09.054

39. Yang, G.; Luo, C.; Mu, X.; Wang, T.; Liu, X.-Y. Chem. Commun. 2012, 48, 5880. doi:10.1039/c2cc30731f

40. Li, W.; Huang, J.; Wang, J. Org. Biomol. Chem. 2013, 11, 400-406. doi:10.1039/c2ob27102h

41. Koz, G.; Koz, Ö. Z. Naturforsch., B: J. Chem. Sci. 2017, 72, 647-653. doi:10.1515/znb-2017-0040

42. Voskressensky, L. G.; Festa, A. A.; Storozhenko, O. A.; Le, T. A.; Nguyen, V. T.; Varlamov, A. V. RSC Adv. 2015, 5, 12442-12445. doi:10.1039/c4ra14122a

43. Voskressensky, L. G.; Storozhenko, O. A.; Festa, A. A.; Novikov, R. A.; Varlamov, A. V. Synthesis 2017, 49, 2753-2760. doi:10.1055/s-0036-1589496

44. Golantsov, N. E.; Nguyen, H. M.; Varlamov, A. V.; Aksenov, A. V.; Voskressensky, L. G. Chem. Heterocycl. Compd. 2017, 53, 446-450. doi:10.1007/s10593-017-2073-1

45. Festa, A. A.; Storozhenko, O. A.; Bella Ndoutoume, D. R.; Varlamov, A. V.; Voskressensky, L. G. Mendeleev Commun. 2017, 27, 451-453. doi:10.1016/j.mencom.2017.09.006

46. Gulevskaya, A. V.; Pozharskii, A. F. The S N H -Amination of Heteroaromatic Compounds. Metal Free C-H Functionalization of Aromatics; Topics in Heterocyclic Chemistry; Springer International Publishing: Cham, Switzerland, 2013; pp 179-239. doi:10.1007/7081_2013_114

47. Ye, M.-C.; Yang, Y.-Y.; Tang, Y.; Sun, X.-L.; Ma, Z.; Qin, W.-M. Synlett 2006, 1240-1244. doi:10.1055/s-2006-932472

48. Chen, W.; Cai, Y.; Fu, X.; Liu, X.; Lin, L.; Feng, X. Org. Lett. 2011, 13, 4910-4913. doi:10.1021/ol2019949

49. Nickerson, D. M.; Mattson, A. E. Chem. - Eur. J. 2012, 18, 8310-8314. doi:10.1002/chem.201201206

50. Gao, Y.; Du, D.-M. Tetrahedron: Asymmetry 2013, 24, 1312-1317. doi:10.1016/j.tetasy.2013.08.018

51. Desyatkin, V. G.; Beletskaya, I. P. Synthesis 2017, 49, 4327-4334. doi:10.1055/s-0036-1589024

52. Feofanov, M. N.; Anokhin, M. V.; Averin, A. D.; Beletskaya, I. P. Synthesis 2017, 49, 5045-5058. doi:10.1055/s-0036-1589068 


\section{License and Terms}

This is an Open Access article under the terms of the Creative Commons Attribution License

(http://creativecommons.org/licenses/by/4.0). Please note that the reuse, redistribution and reproduction in particular requires that the authors and source are credited.

The license is subject to the Beilstein Journal of Organic Chemistry terms and conditions:

(https://www.beilstein-journals.org/bjoc)

The definitive version of this article is the electronic one which can be found at:

doi:10.3762/bjoc. 14.287 